\title{
ACIDIFICATION OF PHYTASE TREATED DIET IMPROVES THE BODY COMPOSITION AND BONE MINERALIZATION OF JUVENILE ROHU (Labeo rohita)
}

\author{
S. Z. H. Shah ${ }^{1 *}$, M. Fatima ${ }^{2}$, M. Afzal ${ }^{3}$, S. M. Hussain ${ }^{4}$, H. Azmat ${ }^{2}$, M. Bilal ${ }^{5}$ and T. Ahmed ${ }^{6}$ \\ ${ }^{1}$ Department of Zoology, University of Gujrat, Gujrat, Pakistan; ${ }^{2}$ Department of Fisheries and Aquaculture, University \\ of Veterinary and Animal Sciences, Lahore, Pakistan; ${ }^{3}$ Fish Nutrition Laboratory, Department of Zoology, Wildlife and \\ Fisheries, University of Agriculture, Faisalabad; ${ }^{4}$ Fish Nutrition Laboratory, Department of Zoology, Government \\ College University, Faisalabad, Pakistan; ${ }^{5}$ School of life Science \\ and Food Engineering, Huaiyin Institute of Technology, Huaian, China; ${ }^{6}$ Department of Life Sciences, Khwaja Fareed \\ University of Engineering and Information Technology, Rahim Yar Khan, Pakistan. \\ *Corresponding author’s E-mail: zakiruaf@gmail.com; dr.zakirhussain@uog.edu.pk
}

\begin{abstract}
A $3 \times 3$ factorial feeding experimental was performed to find out the role of citric acid and phytase supplementations and interaction in improving body chemical composition and bone mineralization by adding them in plant based diet of rohu (Labeo rohita) juveniles. At first, the basal diet having citric acid at three different levels was supplemented i.e. $0 \%$, $1.5 \%$ and $3 \%$, and then three different phytase levels $\left(0 \mathrm{FTU} \mathrm{kg}-1,750 \mathrm{FTU} \mathrm{kg}^{-1}\right.$ and $\left.1000 \mathrm{FTU} \mathrm{kg}^{-1}\right)$ were supplemented further with each level of citric acid. Hence, total 9 experimental diets were formulated in this feeding trial. The results revealed that the concentration of total ash, crude protein and dry matter content significantly increased $(p \leq 0.05)$, when treated with citric acid and phytase. However, contents of crude fat showed a reduced level in the carcass of juveniles by feeding both additives. The supplementation of citric acid and phytase both significantly $(p \leq 0.05)$ affected the bone mineralization of fish. An increasing trend was observed for the body proximate analysis and bone mineral concentrations with an increase of supplements level in the diet. Conclusively, the results of this experiment showed that the supplementation of citric acid and phytase in the diet of L. rohita improved body composition and bone mineralization.
\end{abstract}

Key words: Phytase, citric acid, rohu (Labeo rohita), bone mineralization, body mineralization, body proximate composition

Abbreviations: Phytase (PHY); Citric Acid (CA); Labeo rohita (L. rohita); Analysis of variance (ANOVA) Published first online January 24, 2021

\section{INTRODUCTION}

Aquaculture is rapidly growing sector which acts as important component of food security (Ibrahem et al., 2010). Success of aquaculture mainly depends upon the nutritional status as well as economy of feed for cultured species. In modern day intensive culture system feed cost accounts for $50 \%$ of the total culture economy (Ibrahem et al., 2010). Fish nutritionists, now a day, are focusing on low cost feed production with a replacement of fishmeal with plant by-products (Carter and Hauler, 2000). Soybean meal is assumed to be best feed ingredient because of its balanced nutritional status and also used as feed source for a number of fish species (Gatlin et al., 2007).

In the fish feed, the presence of anti-nutritional factors (phytic acid) causes major problems, when plant based proteins are used in the feed. Phytic acid is the main source of phosphorus and account for almost $80 \%$ of the total Phosphorus of plants (Pointillart et al., 1987) and also restricts the digestibility of nutritionally significant nutrients including proteins (Liu et al., 2012);
Published Final August 07, 2021.

and minerals, especially $\mathrm{Ca}, \mathrm{Mg}, \mathrm{K}, \mathrm{Zn}, \mathrm{Cu}$ and $\mathrm{Fe}$ (Sugiura et al., 2001) leading to their biologically unavailability and growth depression.

Nutrients bound as phytic acid can only be made available to fish when are hydrolysed by phytase, an enzyme also known as myo-inositol hexaphosphate phosphohydrolase (Francis et al., 2001; Cao et al., 2007; Gatlin et al., 2007). Phytase degrades phytate to monophosphate and di-phosphate compounds making them available to monogastric animals (Mitchell et al., 1997). In monogastric animals, phytase is generally used as feed additive in the diet. In fish feed, phytase addition has shown increased utilization of phytate bound phosphorus in different fish species i.e. common carp (Schafer et al., 1995), channel catfish (Li and Robinson, 1997), Nile tilapia (Furuya et al., 2001; Tudkaew et al., 2008; Verlhac-Trichet et al., 2014), rainbow trout (Dalsgaard et al., 2009; Verlhac-Trichet et al., 2014). In yellow catfish, the $\mathrm{P}, \mathrm{Ca}$ and $\mathrm{Mg}$ content of vertebrae and whole body was significantly enhanced (Zhu et al., 2014) and a similar increase in $\mathrm{Ca}, \mathrm{P} \mathrm{Mg}$ and $\mathrm{Zn}$ contents of whole 
Salmo salar (Denstadli et al., 2007) has also been evident.

It has been shown by various studies that the accessibility of biologically important minerals in fish is affected by the $\mathrm{pH}$ of gut (Sugiura et al., 1998; Vielma et al., 1999). Dietary supplementation of organic acids has the tendency to increase the minerals absorption by decreasing the intestinal $\mathrm{pH}$ (Jongbloed, 1987). Decreased intestinal $\mathrm{pH}$ enhances the absorption of phosphorus by increasing the phosphorus phytate solubility (Cross et al., 1990; Ravindran and Kornegay, 1993). Along with its effect on intestinal $\mathrm{pH}$, the dietary organic acid act as chelating agent which increases the absorption of certain minerals, that binds many cations present in the intestine (Wood and Serfaty-Lacrosniere, 1992). Organic acid has been proved an efficient antimicrobial agent which enhances disease resistance leading to improved growth, nutrient utilization (NRC, 2011). Moreover, studies have showed increased $P$ and Ca level of Huso huso (Khajepour and Hosseini, 2011; 2012) and increased mineral contents of rohu (L. rohita) (Afzal et al., 2020) in response to organic acid supplementation.

Phytase works optimally at 2.5 and 5.0-5.5 pH (Simons et al., 1990) which can be achieved by additing acid in fish diet. Citric acid (CA) addition lowers gastrointestinal $\mathrm{pH}$ of fish stomach to optimum range of phytase action. Hence, considered as an efficient method to enhance phytase activity (Nourmohammadi et al., 2011). Phromkunthong et al. (2010) reported that the citric acid and phytase interaction has improved bone mineral contents of Cyprinus carpio. Therefore, the present study was aimed at evaluation of phytase and citric acid efficacy for L. rohita composition.

\section{MATERIALS AND METHODS}

Experimental diets: Nine isonitrogenous (27.54 \pm 0.49$)$, isolipidic $(8.00 \pm 0.21)$ and isocaloric $(3.67 \pm 0.48)$ experimental diets were formulated in the Fish Nutrition Laboratory, Department of Zoology, Wildlife and Fisheries, University of Agriculture, Faisalabad, Pakistan. Soybean being a major protein source contributed to about $57.77 \%$ crude protein of diet while fish meal (33.99\%), rice polish $(4.25 \%)$ and wheat flour $(3.99 \%)$ also added share to total crude protein of diet. For lipid source as well as feed attractant fish oil was used. All experimental diets were similar in composition apart from the levels of citric acid and phytase supplementation. In experimental diets, the citric acid and phytase were added at levels of $0,1.5$ and $3 \%$ and 0,750 and $1000 \mathrm{FTU} / \mathrm{kg}$, respectively. Dry ingredients of feed were powder ground to a particle size of $0.05 \mathrm{~mm}$ in cereal grinding machine (FFC-45, JIMO, China). Citric acid was added into dry ingredients and mixed electrically with gradual addition of fish oil. For the formation of dough, water was added upto $15 \%$, which was further processed to make pallets $(3 \mathrm{~mm})$ through hand palletizer. Afterwards, pellets of every level of citric acid were sprayed with three concentrations of phytase (Phyzme®xP 10000 FTUg $^{-1}$, Damisco Animal Nutrition. Fin-65 101 Vaasa Finland) in such a way that $0.5 \mathrm{~g}$ phytase gave 10000 FTU (Robinson et al., 2002). Pellets were blow dried up to $10 \%$ moisture then sealed in airtight polythene bags and stored at $-20^{\circ} \mathrm{C}$ throughout the feeding trial. Ingredients and proximate composition of experimental diets is given in Table 1 . A $3^{2}$ factorial experiment under completely randomized design was followed for feeding trial with three replicates of each experimental diet.

Rearing conditions and Experimental fish: Rohu ( $L$. rohita) juveniles were taken from Govt. fish seed hatchery, Faisalabad, Pakistan. Upon arrival at laboratory fish were salt $(5 \mathrm{~g} \mathrm{NaCl} / \mathrm{kg})$ bathed and stored for acclimation. The basal diet was given to fish one a day during acclimation period with round the clock aeration, to each experimental unit. Upon acclimation of two weeks 15 fish (average mean weight $=107.69 \pm 1.32 \mathrm{~g}$ ) were randomly distributed into each of 27 experimental tanks with $70 \mathrm{~L}$ water capacity. L. rohita were fed manually at 09:00 and 17:00 daily upto apparent satiation. After 3 hours feeding, the experimental tanks were cleaned and again filled with filtered, dechlorinated public utility water. Mean water temperature (24.9$\left.28.7^{\circ} \mathrm{C}\right), \mathrm{pH}$ (7.4-8.6) and dissolved oxygen (5.8-7.3 $\mathrm{mg} / \mathrm{L})$ were maintained throughout the feeding trial of 10 weeks within the recommended range for species culture.

Collection of sample and analysis: On the termination of feeding trial, 24 hours after last feeding, fish were anesthetized using $3000 \mathrm{mg} / \mathrm{L}$ clove oil solution for 40 $60 \mathrm{sec}$ (Khajepour et al., 2012) and sacrificed. Ten fish were randomly selected from each tank minced, dried at $60^{\circ} \mathrm{C}$, pulverized and used for mineral and whole body proximate analysis. For the analysis of mineral contents of bones, five whole fish were boiled until stripping off flesh from bones (approximately 15 mins). Bones were slightly brushed to remove soft tissues, rinsed with distilled water and for $2 \mathrm{~h}$ oven dried the sample for $2 \mathrm{~h}$ at $110^{\circ} \mathrm{C}$. Bones were defatted in anhydrous ethyl ether and crushed in mortar and pestle. For estimation of minerals dried fish samples were acid digested, and $\mathrm{Mg}$, $\mathrm{Ca}, \mathrm{Fe}, \mathrm{Mn}, \mathrm{Cu}$ and $\mathrm{Zn}$ contents were estimated by atomic absorption spectrophotometer (Hitachi Polarized Zeeman AAS, Z-8200, Japan) according to the official method 968.08 of the AOAC (AOAC, 1997). K and $\mathrm{Na}$ were estimated on flame photometer (Jenway PFP-7, UK) while P contents by UV-VIS spectrophotometer (U-2001, Hitachi) at $750 \mathrm{~nm}$ absorbance after oxidation with molybdate reagent. Standard AOAC (1997) methods were adopted for proximate composition (crude fats, dry matter and crude protein) of diet and whole body. 
Statistical analysis: Using CoStat computer package (Version 6.303, PMB 320, Monterey, CA, 93940 USA), two-way analysis of variance (ANOVA) was applied on the experimental data to study the efficacy of phytase and citric acid supplementation and interaction between these two supplements. For the determination of differences among means Tukey`s Honestly Significant Difference Test was applied (Snedecor and Conhran, 1991). Significant differences were observed at $p \leq 0.05$.

\section{RESULTS}

Body Proximate Composition: Proximate composition of whole body of Rohu in response to dietary citric acid and phytase is given in Table 2 . The results indicated that the phytase supplementation improved the proximate composition of juvenile's whole body. Improved crude protein, total ash and dry matter $(p \leq 0.05)$, meanwhile reduced crude fat in the body of fish was observed in groups having phytase supplemented diet. In the same trend, dietary supplementation of CA also enhanced the whole body nutrient contents of juveniles. Except crude fat, which was decreased, all the other parameters (crude protein, dry matter and total ash) were increased significantly $(p \leq 0.05)$ with dietary CA treatment response. Interaction plots of $\mathrm{CA}$ and $\mathrm{PHY}$ showed strong interaction between both the supplements for proximate composition of juvenile's body. An increasing trend was observed for the crude protein, dry matter and total ash concentrations with an increment in concentrations of the supplements. Maximum increase in these parameters (total ash, crude protein and dry matter) was recorded at highest tested levels of PHY (1000 FTU/kg) and CA (3\%) while highly reduced crude fat level was also recorded on these same levels of both the supplements. Two-way ANOVA results also showed a significant positive interaction for crude fat and total ash concentrations in the juveniles.
Response of Whole-body Mineralization: Whole body mineral contents of rohu juveniles fed on CA and PHY supplemented diets is shown in Table 3. All the minerals ( $\mathrm{Ca}, \mathrm{P}, \mathrm{Mg}, \mathrm{Zn}, \mathrm{K}, \mathrm{Na}, \mathrm{Mn}, \mathrm{Cu}$ and $\mathrm{Fe}$ ) which were observed showed higher contents in fish whole body as compare to control fish in PHY supplemented groups. Their concentration was affected significantly by the amount of PHY fed. Highest deposition of these minerals was detected in T3 fish diet (that was supplemented with 1000 FTU/kg diet). Main effect data of CA supplementation indicated a significantly enhanced mineralization of whole body. Concentration of minerals was also affected by the amount of CA given to the fish. Highest mineral deposition was recorded against to $3 \%$ $\mathrm{CA}$ level. Interactions of both supplements (PHY and CA), improved the amount of these minerals (except $\mathrm{Zn}$ ) in the body. Test diets having $1000 \mathrm{FTU} / \mathrm{kg} \mathrm{PHY}$ and $3 \%$ $\mathrm{CA}$ resulted in maximum deposition of minerals in the fish body.

Bone Mineralization: Effect of CA and PHY on mineralization of bones of rohu juveniles is given in Table 4. PHY addition significantly enhanced the minerals contents in bones. Its supplementation showed dose dependent effect on bone mineralization. Highest amount of minerals deposition was observed in group having supplementation of $1000 \mathrm{FTU} / \mathrm{kg}$ PHY level in the diet. Like that supplementation of $\mathrm{CA}$ also improved mineral contents in fish bones. Maximum deposition of $\mathrm{K}, \mathrm{Na}, \mathrm{Cu}, \mathrm{Zn}$ and $\mathrm{Fe}$ were recorded in fish having $1.5 \%$ $\mathrm{CA}$ while $\mathrm{P}, \mathrm{Ca}$ and $\mathrm{Mn}$ showed their utmost deposition at 3\% CA level. Interaction plots represent a strong interaction among $\mathrm{CA}$ and $\mathrm{PHY}$ for bone mineralization. Likewise, whole body proximate analysis, increasing trend in deposition of $\mathrm{Na}, \mathrm{K}, \mathrm{Na}, \mathrm{Mg}, \mathrm{Zn}, \mathrm{P}, \mathrm{Fe}$, and $\mathrm{Cu}$ in bones of fish was observed with increasing the concentrations of PHY and CA.

Table 1. Composition of experimental diets.

\begin{tabular}{|c|c|c|c|c|c|c|c|c|c|}
\hline CA (\%) & & 0 & & & 1.5 & & & 3 & \\
\hline PHY (FTU/kg) & 0 & 750 & 1000 & $\mathbf{0}$ & 750 & 1000 & $\mathbf{0}$ & 750 & 1000 \\
\hline Soybean meal & 43 & 43 & 43 & 43 & 43 & 43 & 43 & 43 & 43 \\
\hline Fish meal & 24 & 24 & 24 & 24 & 24 & 24 & 24 & 24 & 24 \\
\hline Rice polish & 13 & 13 & 13 & 13 & 13 & 13 & 13 & 13 & 13 \\
\hline Wheat flour & 10 & 10 & 10 & 10 & 10 & 10 & 10 & 10 & 10 \\
\hline Fish oil & 6 & 6 & 6 & 6 & 6 & 6 & 6 & 6 & 6 \\
\hline Vitamin premix & 1 & 1 & 1 & 1 & 1 & 1 & 1 & 1 & 1 \\
\hline Mineral mixture & 1 & 1 & 1 & 1 & 1 & 1 & 1 & 1 & 1 \\
\hline Ascorbic acid & 1 & 1 & 1 & 1 & 1 & 1 & 1 & 1 & 1 \\
\hline Chromic oxide & 1 & 1 & 1 & 1 & 1 & 1 & 1 & 1 & 1 \\
\hline Total & 100 & 100 & 100 & 100 & 100 & 100 & 100 & 100 & 100 \\
\hline \multicolumn{10}{|c|}{ Proximate composition } \\
\hline Dry matter & 92.02 & 92.14 & 93.07 & 93.13 & 92.72 & 93.31 & 93.11 & 93.63 & 93.83 \\
\hline Crude protein & 26.37 & 27.33 & 27.66 & 28.07 & 28.03 & 27.57 & 28.04 & 27.49 & 27.42 \\
\hline Crude fat & 7.81 & 7.875 & 7.99 & 7.88 & 7.93 & 8.00 & 7.95 & 7.99 & 8.61 \\
\hline Gross energy & 3.69 & 3.645 & 3.71 & 3.79 & 3.69 & 3.67 & 3.64 & 3.65 & 3.61 \\
\hline
\end{tabular}


Table 2. The influence of citric acid and phytase supplementation on the whole-body proximate composition of (g/kg) of $L$. rohita

\begin{tabular}{|c|c|c|c|c|c|c|c|c|c|c|c|c|c|}
\hline \multirow{2}{*}{$\begin{array}{l}\text { CA level (\%) } \\
\text { PHY Level (FTU/kg) }\end{array}$} & \multicolumn{3}{|c|}{$\mathbf{0}$} & \multicolumn{3}{|c|}{1.5} & \multicolumn{3}{|c|}{3} & \multirow{2}{*}{ PSE } & \multicolumn{3}{|c|}{ ANOVA } \\
\hline & 0 & 750 & 1000 & 0 & 750 & 1000 & 0 & 750 & 1000 & & CA & PHY & CA X PHY \\
\hline Dry matter & $232.1^{\mathrm{e}}$ & $253.25^{\mathrm{c}}$ & $244.20^{\mathrm{d}}$ & $244.7^{\mathrm{d}}$ & $256.7^{\mathrm{bc}}$ & $254.7^{\mathrm{c}}$ & $243.4^{\mathrm{d}}$ & $257.5^{\mathrm{b}}$ & $261.5^{\mathrm{a}}$ & 1.41 & $\leq 0.05$ & $\leq 0.05$ & NS \\
\hline Crude Protein & $214.4^{\mathrm{f}}$ & $227.05^{\mathrm{e}}$ & $234.95^{\mathrm{d}}$ & $236.9^{\mathrm{cd}}$ & $247.05^{b}$ & $248.95^{b}$ & $238.4^{\mathrm{c}}$ & $247.45^{\mathrm{b}}$ & $253.6^{\mathrm{a}}$ & 1.55 & $\leq 0.05$ & $\leq 0.05$ & NS \\
\hline Crude fat & $52.45^{\mathrm{a}}$ & $46.15^{\mathrm{b}}$ & $41.85^{\mathrm{c}}$ & $41.55^{\mathrm{c}}$ & $34.4^{\mathrm{e}}$ & $37.45^{\mathrm{d}}$ & $42.15^{\mathrm{c}}$ & $31.85^{\mathrm{f}}$ & $28.8^{\mathrm{g}}$ & 0.84 & $\leq 0.05$ & $\leq 0.05$ & $\leq 0.05$ \\
\hline Total ash & $33.00^{\mathrm{f}}$ & $38.50^{\mathrm{e}}$ & $39.65^{\text {de }}$ & $42.1^{\mathrm{c}}$ & $41.5^{\mathrm{cd}}$ & $44.3^{\mathrm{b}}$ & $40.25^{\mathrm{d}}$ & $46.3^{\mathrm{a}}$ & $45.4^{\mathrm{ab}}$ & 0.86 & $\leq 0.05$ & $\leq 0.05$ & $\leq 0.05$ \\
\hline
\end{tabular}

Means within rows having different superscripts are significantly different at $\mathrm{P} \leq 0.05$

Data are means of three replicates

$\mathrm{PSE}=$ pooled $\mathrm{SE}=\sqrt{\mathrm{MSE}} / \mathrm{n}$ (where MSE $=$ mean-square error)

Table 3. The influence of citric acid and phytase supplementation on whole body mineralization of L. rohita.

\begin{tabular}{|c|c|c|c|c|c|c|c|c|c|c|c|c|c|}
\hline \multirow{2}{*}{$\begin{array}{l}\text { CA level (\%) } \\
\text { PHY Level (FTU/kg) }\end{array}$} & \multicolumn{3}{|c|}{$\mathbf{0}$} & \multicolumn{3}{|c|}{1.5} & \multicolumn{3}{|c|}{3} & \multirow{2}{*}{ PSE } & \multicolumn{3}{|c|}{ ANOVA } \\
\hline & $\mathbf{0}$ & 750 & 1000 & $\mathbf{0}$ & 750 & 1000 & 0 & $\mathbf{7 5 0}$ & 1000 & & CA & PHY & $\mathbf{C A} \times \mathbf{P H Y}$ \\
\hline $\mathrm{P}(\%)$ & $0.81^{\mathrm{f}}$ & $0.91^{\mathrm{f}}$ & $0.94^{\mathrm{e}}$ & $0.96^{\mathrm{d}}$ & $1.06^{\mathrm{c}}$ & $1.09^{\mathrm{b}}$ & $0.92^{\mathrm{f}}$ & $1.10^{\mathrm{b}}$ & $1.13^{\mathrm{a}}$ & 0.01 & $\leq 0.05$ & $\leq 0.05$ & $\leq 0.05$ \\
\hline $\mathrm{Ca}(\%)$ & $0.73^{\mathrm{h}}$ & $0.805^{\mathrm{g}}$ & $0.851^{\mathrm{d}}$ & $0.83^{\mathrm{e}}$ & $0.93^{\mathrm{c}}$ & $0.92^{\mathrm{c}}$ & $0.83^{\mathrm{f}}$ & $0.95^{\mathrm{b}}$ & $0.98^{\mathrm{a}}$ & 0.01 & $\leq 0.05$ & $\leq 0.05$ & $\leq 0.05$ \\
\hline $\operatorname{Mg}(\%)$ & $1.25^{\mathrm{g}}$ & $1.75^{\mathrm{f}}$ & $1.95^{\mathrm{e}}$ & $1.70^{\mathrm{f}}$ & $2.45^{\mathrm{d}}$ & $2.75^{\mathrm{c}}$ & $1.85^{\mathrm{ef}}$ & $2.95^{\mathrm{b}}$ & $3.25^{\mathrm{a}}$ & 0.05 & $\leq 0.05$ & $\leq 0.05$ & $\leq 0.05$ \\
\hline $\mathrm{Na}(\mathrm{mg} / \mathrm{g})$ & $2.60^{\mathrm{e}}$ & $3.25^{\mathrm{d}}$ & $3.7^{\mathrm{c}}$ & $3.40^{\mathrm{d}}$ & $5.05^{\mathrm{b}}$ & $5.25^{\mathrm{b}}$ & $3.70^{\mathrm{c}}$ & $5.55^{\mathrm{a}}$ & $5.75^{\mathrm{a}}$ & 0.11 & $\leq 0.05$ & $\leq 0.05$ & $\leq 0.05$ \\
\hline $\mathrm{K}(\%)$ & $5.65^{f}$ & $6.05^{\mathrm{e}}$ & $6.25^{\mathrm{de}}$ & $6.40^{\mathrm{d}}$ & $7.85^{\mathrm{c}}$ & $8.05^{b c}$ & $6.45^{\mathrm{d}}$ & $8.20^{\mathrm{b}}$ & $8.70^{\mathrm{a}}$ & 0.11 & $\leq 0.05$ & $\leq 0.05$ & $\leq 0.05$ \\
\hline Mn (ug/g) & $7.45^{d}$ & $7.85^{\mathrm{c}}$ & $8.00^{c}$ & $7.75^{\mathrm{c}}$ & $9.40^{\mathrm{b}}$ & $9.4^{\mathrm{b}}$ & $7.95^{\mathrm{c}}$ & $9.65^{b}$ & $10.0^{\mathrm{a}}$ & 0.11 & $\leq 0.05$ & $\leq 0.05$ & $\leq 0.05$ \\
\hline $\mathrm{Fe}(\mathrm{ug} / \mathrm{g})$ & $31.0 \mathrm{e}$ & $36.0^{\mathrm{d}}$ & $37.5^{\mathrm{d}}$ & $36.0^{\mathrm{d}}$ & $51.0^{\mathrm{b}}$ & $52.0^{\mathrm{b}}$ & $38.5^{\mathrm{c}}$ & $51.5^{b}$ & $55.0^{\mathrm{a}}$ & 1.01 & $\leq 0.05$ & $\leq 0.05$ & $\leq 0.05$ \\
\hline $\mathrm{Cu}(\mathrm{ug} / \mathrm{g})$ & $1.40^{\mathrm{g}}$ & $1.75^{\mathrm{f}}$ & $2.05^{\mathrm{e}}$ & $2.10^{\mathrm{de}}$ & $3.45^{\mathrm{c}}$ & $3.65^{\mathrm{bc}}$ & $2.30^{\mathrm{d}}$ & $3.80^{\mathrm{b}}$ & $4.15^{\mathrm{a}}$ & 0.11 & $\leq 0.05$ & $\leq 0.05$ & $\leq 0.05$ \\
\hline $\mathrm{Zn}(\mathrm{ug} / \mathrm{g})$ & $1.40^{\mathrm{b}}$ & $1.75^{\mathrm{b}}$ & $2.05^{\mathrm{b}}$ & $2.10^{\mathrm{ab}}$ & $3.45^{\mathrm{ab}}$ & $3.65^{\mathrm{ab}}$ & $2.30^{\mathrm{ab}}$ & $3.80^{\mathrm{ab}}$ & $4.15^{\mathrm{a}}$ & 0.90 & $\leq 0.05$ & $\leq 0.05$ & NS \\
\hline
\end{tabular}

Means within rows having different superscripts are significantly different at $\mathrm{P} \leq 0.05$

Data are means of three replicates

$\mathrm{PSE}=$ pooled $\mathrm{SE}=\sqrt{\mathrm{MSE}} / \mathrm{n}($ where $\mathrm{MSE}=$ mean-squared error $)$

Table 4. The influence of citric acid and phytase supplementation on bone mineralization of L. rohita.

\begin{tabular}{|c|c|c|c|c|c|c|c|c|c|c|c|c|c|}
\hline \multirow{2}{*}{$\begin{array}{l}\text { CA level (\%) } \\
\text { PHY Level (FTU/kg) }\end{array}$} & \multicolumn{3}{|c|}{$\mathbf{0}$} & \multicolumn{3}{|c|}{1.5} & \multicolumn{3}{|c|}{3} & \multirow{2}{*}{ PSE } & \multicolumn{3}{|c|}{ ANOVA } \\
\hline & $\mathbf{0}$ & 750 & 1000 & $\mathbf{0}$ & 750 & 1000 & $\mathbf{0}$ & 750 & 1000 & & $\mathbf{C A}$ & PHY & $\mathbf{C A} \times \mathbf{P H Y}$ \\
\hline $\mathbf{P}(\%)$ & $10.15^{\mathrm{b}}$ & $10.85^{\mathrm{ab}}$ & $10.8^{\mathrm{ab}}$ & $10.75^{\mathrm{ab}}$ & $11.8^{\mathrm{ab}}$ & $11.05^{\mathrm{ab}}$ & $10.7^{\mathrm{a}}$ & $11.8^{\mathrm{ab}}$ & $12.05^{\mathrm{a}}$ & 0.10 & $\leq 0.05$ & $\leq 0.05$ & $\leq 0.05$ \\
\hline $\mathrm{Ca}(\%)$ & $21.65^{\mathrm{e}}$ & $24.01^{\mathrm{d}}$ & $25.25^{\mathrm{c}}$ & $21.8^{\mathrm{e}}$ & $26.15^{\mathrm{b}}$ & $27.27^{\mathrm{a}}$ & $21.6^{\mathrm{e}}$ & $27.2^{\mathrm{a}}$ & $27.55^{\mathrm{a}}$ & 0.43 & $\leq 0.05$ & $\leq 0.05$ & $\leq 0.05$ \\
\hline $\operatorname{Mg}(\%)$ & $0.32^{\mathrm{f}}$ & $0.44^{\mathrm{e}}$ & $0.45^{\mathrm{de}}$ & $0.45^{\text {de }}$ & $0.54^{\mathrm{c}}$ & $0.54^{\mathrm{c}}$ & $0.46^{\mathrm{d}}$ & $0.56^{\mathrm{b}}$ & $0.62^{\mathrm{a}}$ & 0.83 & $\leq 0.05$ & $\leq 0.05$ & $\leq 0.05$ \\
\hline $\mathrm{Na}(\mathrm{mg} / \mathrm{g})$ & $1.35^{\mathrm{g}}$ & $1.56^{\mathrm{d}}$ & $1.5^{\mathrm{e}}$ & $1.48^{\mathrm{ef}}$ & $1.63^{\mathrm{b}}$ & $1.60^{\mathrm{c}}$ & $1.46^{\mathrm{f}}$ & $1.69^{\mathrm{a}}$ & $1.68^{\mathrm{a}}$ & 1.59 & $\leq 0.05$ & $\leq 0.05$ & $\leq 0.05$ \\
\hline$K(\%)$ & $0.34^{\mathrm{g}}$ & $0.44^{\mathrm{e}}$ & $0.48^{\mathrm{cd}}$ & $0.41^{\mathrm{f}}$ & $0.49^{\mathrm{c}}$ & $0.54^{\mathrm{b}}$ & $0.47^{\mathrm{cd}}$ & $0.58^{\mathrm{a}}$ & $0.57^{\mathrm{a}}$ & 1.17 & $\leq 0.05$ & $\leq 0.05$ & $\leq 0.05$ \\
\hline Mn (ug/g) & $44.7^{\mathrm{e}}$ & $49.1^{\mathrm{cd}}$ & $50.15^{\mathrm{c}}$ & $48.45^{\mathrm{d}}$ & $53.15^{\mathrm{ab}}$ & $54.25^{\mathrm{a}}$ & $47.95^{\mathrm{d}}$ & $52.55^{\mathrm{b}}$ & $54.05^{\mathrm{a}}$ & 0.63 & $\leq 0.05$ & $\leq 0.05$ & $\leq 0.05$ \\
\hline $\mathrm{Fe}(\mathrm{ug} / \mathrm{g})$ & $31.55^{\mathrm{e}}$ & $36.45^{\mathrm{d}}$ & $38.2^{\mathrm{cd}}$ & $36.65^{\mathrm{d}}$ & $41.5^{\mathrm{b}}$ & $42.7^{\mathrm{b}}$ & $38.95^{\mathrm{c}}$ & $42.2^{\mathrm{b}}$ & $45.7^{\mathrm{a}}$ & 1.20 & $\leq 0.05$ & $\leq 0.05$ & $\leq 0.05$ \\
\hline $\mathrm{Cu}$ (ug/g) & $11.4^{\mathrm{h}}$ & $11.75^{\mathrm{g}}$ & $12.05^{\mathrm{f}}$ & $12.1^{\text {ef }}$ & $12.45^{\mathrm{cd}}$ & $12.65^{b c}$ & $12.3^{\mathrm{de}}$ & $12.8^{\mathrm{b}}$ & $13.15^{\mathrm{a}}$ & 0.13 & $\leq 0.05$ & $\leq 0.05$ & $\leq 0.05$ \\
\hline $\mathrm{Zn}(\mathrm{ug} / \mathrm{g})$ & $116.05^{\mathrm{h}}$ & $119.55^{\mathrm{g}}$ & $122.2^{\mathrm{ef}}$ & $120.35^{\mathrm{fg}}$ & $124.95^{\mathrm{cd}}$ & $125.7^{\mathrm{c}}$ & $123.45^{\mathrm{de}}$ & $130^{\mathrm{b}}$ & $132.7^{\mathrm{a}}$ & 1.20 & $\leq 0.05$ & $\leq 0.05$ & NS \\
\hline
\end{tabular}

Means within rows having different superscripts are significantly different at $\mathrm{P} \leq 0.05$

Data are means of three replicates

$\mathrm{PSE}=$ pooled $\mathrm{SE}=\sqrt{\mathrm{MSE}} / \mathrm{n}($ where $\mathrm{MSE}=$ mean-squared error $)$ 


\section{DISCUSSION}

Phytase hydrolysed the phytate, which is present in plants related feed stuffs, and it ultimately improves the phytate $\mathrm{P}$ and other minerals utilization (Cheng and Hardy, 2002). In the present study, supplementation of phytase enhanced the dry matter content of whole fish body. In contrast to this study, Carter and Sajjadi (2011) observed non-significant changes in dry matter of Atlantic salmon fed on phytase supplemented diets. Denstadli et al. (2007) examined the non-significant changes in dry matter of Salmo salar by adding phytase in fish feed. Contents of crude protein in juvenile's body was improved in phytase supplemented groups. Similar results in Cyprinus carpio were also shown by Sardar et al. (2007). Conversely, many of works cleared that body content of crude protein was significantly affected by dietary phytase supplemented but a negative response on some species such as Gibel carp (Liu et al., 2012), Atlantic salmon (Carter and Sajjadi, 2011), grass carp (Liu et al., 2014) and Salmo salar (Denstadli et al., 2007) has also been reported. Additionally, negative response to whole body crude protein to phytase addition was observed in red sea bream (Laining et al. 2012). In the current study, decrease in level of crude fat of juvenile's body was observed in against phytase addition. Same decrease in crude fat contents in whole body of grass carp (Liu et al., 2014), Salmo salar (Denstadli et al., 2007), and Cyprinus carpio (Sardar et al., 2007) were also observed in response to phytase addition. Contrary to present study, in red sea bream (Laining et al., 2012) and Gibel carp (Liu et al., 2012) non-significant differences among control and PHY treated groups were reported. Enhanced ash content in the whole body of fish were observed, when fish were fed with phytase treated diets which indicate that phytase might enhanced the minerals content of fish body (Sarker et al., 2012). Similar results have also been reported by many preceding studies (Denstadli et al., 2007; Sardar et al., 2007; Carter and Sajjadi, 2011; Liu et al., 2014).

Whole body mineral contents of $L$. rohita were enhanced by citric acid addition $(\mathrm{P} \leq 0.05)$, which indicates phytate hydrolysis. Same results were observed in a study that showed an increased content of $\mathrm{P}, \mathrm{Ca}, \mathrm{K}$, $\mathrm{Mn}, \mathrm{Fe}$ and $\mathrm{Cu}$ in Pagrus major when citric acid (3\%) was added in the diet of fish (Laining et al., 2012). While in another study contradicted results were observed, where organic acid supplementation showed nonsignificant variations to whole body mineral contents of yellow catfish (Zhu et al., 2014), Yellow tail (Sarker et al., 2012), rainbow trout (Pandey and Satoh, 2008) and red sea bream (Hossain et al., 2007). Citric acid when added to phytase supplemented diets showed positive interaction and enhanced mineral contents of rohu. Citric acid reduced intestinal $\mathrm{pH}$ up to range of phytase activity as well as breaks phytate complex physically. Positive interaction was observed in citric acid and phytase in order to enhance mineral ( $\mathrm{Ca}, \mathrm{P}, \mathrm{Na}, \mathrm{Mg}, \mathrm{K}, \mathrm{Fe}, \mathrm{Mn}, \mathrm{Zn}$ and $\mathrm{Cu}$ ) contents of whole rohu. Similar synergistically positive interaction was also reported by Afzal et al. (2020).

Increased bone mineral contents were observed in this study by adding phytase in fish feed. Phytase hydrolyzed phytate and released bound minerals enhancing their free availability and deposition in bones. Similarly, some other studies have reported improved bones $\mathrm{Ca}$ and $\mathrm{P}$ of rainbow trout (Fox and Davies, 2011) and bones $\mathrm{P}, \mathrm{Ca}, \mathrm{Mg}$ and $\mathrm{Zn}$ of red sea bream (Laining et al., 2012) and Salmo salar (Denstadli et al., 2007). However, in a recent study non-significant results of bone minerals were detected by addition of phytase in the feed of fish (Liu et al., 2014). Fish fed citric acid supplemented diet, showed increased mineral contents of bones which may be due to the reason that decreased $\mathrm{pH}$ by acid addition broken down mineral compounds and formed citric acid chelated mineral complexes which were easily absorbed by fish. In agreement to our study, better $\mathrm{Ca}, \mathrm{P}$ and $\mathrm{Zn}$ concentrations in bones of rainbow trout has also been reported (Pandey and Satoh, 2008). Furthermore, citric acid assisted phytase performance by lowering $\mathrm{pH}$ in optimum phytase activity range and enhanced phytate hydrolysis, which alternatively improved minerals availability. Also, Afzal et al. (2020) confirmed that citric acid positively interacted $(p \leq 0.05)$ with phytase for enhancing mineral contents of bones.

Hence, the present study evidenced that that dietary citric acid and microbial phytase are considered efficient dietary supplements to improve the nutrient and mineral profile of rohu (L. rohita) juveniles.

\section{REFERENCES}

Afzal, M., M. Fatima, A. Qamar, M. Farhan and S.Z.H. Shah (2020). Growth, Muscle Proximate Composition and Whole-Body Nutrient Status of Labeo rohita Fed Acidified and Phytase PreTreated Sunflower Meal Based Diet. Pakistan J. Zool. 52: 937-947.

AOAC. (1997). Official Methods of Analysis of AOAC International (16th edn) ed. by P.A. Cunniff. AOAC International, Arlington, VA.

Cao, L., W. Wang, C. Yang, W. Yang, J. Diana, A. Yakupitiyage, Z. Luo and D. Li (2007). Application of microbial phytase in fish feed. Enzyme Microb. Technol. 40: 497-507.

Carter, C.G. and M. Sajjadi (2011). Low fishmeal diets for Atlantic salmon, Salmo salar L., using soy protein concentrate treated with graded levels of phytase. Aquacult. Int. 19: 431-444.

Carter, C.G. and R.C. Hauler (2000). Fish meal replacement by plant meals in extruded feeds for 
Atlantic salmon, Salmo salar L. Aquaculture 185: 299-311.

Cheng, Z.J. and R.W. Hardy (2002). Effect of microbial phytase on apparent nutrient digestibility of barley, canola meal, wheat and wheat middlings, measured in vivo using rainbow trout (Oncorhynchus mykiss). Aquacult. Nutr. 8: 271277.

Cross, H.S., H. Debiec and M. Peterlik (1990). Mechanism and regulation of intestinal phosphate absorption. Miner. Electrolyte Metab. 16: 115-124.

Dalsgaard, J., K.S. Ekmann, P.B. Pedersen and V. Verlhac (2009). Effect of supplemented fungal phytase on performance and phosphorus availability by phosphorus-depleted juvenile rainbow trout (Oncorhynchus mykiss), and on the magnitude and composition of phosphorus waste output. Aquaculture 286: 105-112.

Denstadli, V., T. Storebakken, B. Svihus and A. Skrede (2007). A comparison of online phytase pretreatment of vegetable feed ingredients and phytase coating in diets for Atlantic salmon (Salmo salar L.) reared in cold water. Aquaculture 269: 414-426.

Fox, S.W. and S.J. Davies (2011). Corn-expressed dietry phytase augments vertebral and scale mineral content in juvenile rainbow trout (Oncorhynchus mykiss). Aquacult. Nutr. 17: 840-852.

Francis, G., H.P.S. Makkar and K. Becker (2001). Antinutritional factors present in plant derived alternate fish feed ingredients and their effects in fish. Aquaculture 199: 197-227.

Furuya, W.M., G.S. Gonçalves, V.R.B. Furuya and C. Hayashi (2001). Phytase as feeding for Nile tilapia (Oreochromis niloticus). Performance and digestibility. Rev. Bras. Zootecn. 30: 924929.

Gatlin, D.M., F.T. Barrows, P. Brown, K. Dabrowski, G.T. Gaylord, R.W. Hardy, E. Herman, G. Hu, A. Krogdahl, R. Nelson, K. Overturf, M. Rust, W. Sealey, D. Skonberg, E.J. Souza, D. Stone, R. Wilson and E. Wurtele (2007). Expanding the utilization of sustainable plant products in aquafeeds. Rev. Aquacult. Res. 38: 551-579.

Hossain, M.A., A. Pandey and S. Satoh (2007). Effects of organic acids on growth and phosphorus utilization in red sea bream Pagrus major. Fish. Sci. 73: 1309-1317.

Ibrahem, M.D., M. Fathi, S. Mesalhy and A.M. Abd ElAty (2010). Effect of dietary supplementation of inulin and vitamin $\mathrm{C}$ on the growth, hematology, innate immunity, and resistance of Nile tilapia (Oreochromis niloticus). Fish. Shellfish. Immunol. 29: 241-246.
Jongbloed, A.W. (1987). Phosphorus in the feeding of pigs. PhD Thesis. Univ. Agric., Wageningen, Wageningen.

Khajepour, F. and S.A. Hosseini (2011). Effect of dietary citric acid supplementation and partial replacement of dietary fish meal with soybean meal on calcium and phosphorus of muscle, scute and serum of Beluga, Huso huso. Africa. J. Biotechnol. 10: 14652-14655.

Khajepour, F. and S.A. Hosseini (2012). Calcium and phosphorus status in juvenile Beluga (Huso huso) fed citric acid-supplemented diets. Aquacult. Res. 43: 407-411.

Khajepour, F., S.A. Hosseini and M.R. Imanpour. (2012). Dietary crude protein, citric acid and microbial phytase and them interacts to influence growth performance, muscle proximate composition and hematocrite of common carp, Cyprinus carpio L, Juveniles. J. World Zool. 7: 118-122.

Laining, A., M. Ishikawa, S. Koshio and S. Yokoyama. (2012). Dietry inorganic phosphorus or microbial phytase supplementation improves growth, nutrient utilization and phosphorus mineralization of juvenile red sea bream, Pagrus major, fed soybean- based diets. Aquacult. Nutr. 18: 502-511.

Li, M.H. and E.H. Robinson (1997). Microbial phytase can replace inorganic phosphorus supplements in channel catfish Ictalurus punctatus diets. J. World Aquacult. Soc. 28: 402-406.

Liu, L., Y. Zhou, J. Wu, W. Zhang, K. Abbas, L. XuFang and Y. Luo (2014). Supplemental graded level of neutral phytase using pretreatment and spraying methods in the diet of grass carp, Ctenopharyngodon idellus. Aquacult. Res. 1932-1941.

Liu, L.W., J. Su and Y. Luo (2012). Effect of partial replacement of dietary mono-calcium phosphate with neutral phytase on growth performance and phosphorus digestibility in gibel carp, Carassius auratus gibelio (Bloch). Aquacult. Res. 45: 1404-1413.

Mitchell, B., K. Vogel, L. Pasamontes and A.P. VanLoon (1997). The phytase subfamily of histidine acid phosphatases: isolation of genes for two novel phytases from the fungi Aspergillus terreus and Myceliophora thermophila. Microbiology143(1): 245-252.

Nourmohammadi, R., S.M. Hosseini and H. Farhangfar (2011). Effect of citric acid and microbial phytase on serum enzyme activities and plasma minerals retention in broiler chicks. Afr. J. Biotechnol. 10: 13640-13650.

NRC (National Research Council). (2011). Nutrient requirements of fish and shrimp. National Academies Press, Washington, DC, USA. 
Pandey, A. and S. Satoh (2008). Effects of organic acids on growth and phosphorus utilization in rainbow trout Oncorhynchus mykiss. Fish. Sci. 74: 867874.

Phromkunthong, W., N. Nuntapong and J. Gabaudan (2010). Interaction of phytase RONOZYME® $\mathrm{P}(\mathrm{L})$ and citric acid on the utilization of phosphorus by common carp (Cyprinus carpio). Songklanakarin. J. Sci. Technol. 32: 547-554.

Pointillart, A., A. Fourdin and N. Fontaine (1987). Importance of cereal phytase activity for phytate phosphorus utilization by growing pigs fed diets containing triticale or corn. J. Nutr. 29: 907-912.

Ravindran, V. and E.T. Kornegay (1993). Acidification of weaner pig diets: a review. J. Sci. Food Agric. 62: 313-322.

Robinson, E.H., M.H. Li and B.B. Manning (2002). Comparison microbial phytase and dicalcium phosphate for growth and bone mineralization of pond-raised channel cat fish, (Ictalurus punctatus). J. Appl. Aquacult. 12: 81-88.

Sardar, P., H.S. Randhawa, M. Abid and S.K. Prabhakar (2007). Effect of dietary microbial phytase supplementation on growth performance, nutrient utilization, body compositions and haemato- biochemical profiles of Cyprinus carpio (L.) fingerlings fed soyprotein- based diet. Aquacult. Nutr. 13: 444-456.

Sarker, M.S.A., S. Satoh, K. Kamata, Y. Haga and Y. Yamamoto (2012). Partial replacement of fish meal with plant protein sources using organic acids to practical diets for juvenile yellowtail, Seriola quinqueradiata. Aquacult. Nutr. 18: 8189.

Schafer, A., W.M. Koppe, K.H. Meyer-Burgdorff and K.D. Gunther (1995). Effects of microbial phytase on the utilization of native phosphorus by carp in a diet based on soybean meal. Water Sci. Tech. 31: 149-155.

Simons, P.C.M., H.A.J. Versteegh, A.W. Jongbloed, P.A. Kemme, P. Slump, K.D. Bos, W.G. E. Wolters, R.F. Beudeker and G.J. Verschoor (1990). Improvement of phosphorus availability by microbial phytase in broilers and pigs. Britsh. J. Nutr. 64: 525-540.

Snedecor, G.W. and W.G. Conhran (1991). Statistical Methods. $8^{\text {th }}$ Ed. Iowa State; Univ. Press, Ames. USA. 503 p.

Sugiura, S.H., F.M. Dong and R.W. Hardy (1998). Effect of dietary supplements on the availability of minerals in fish meal: preliminary observation. Aquaculture 160: 283-303.

Sugiura, S.H., J. Gabaudan, F.M. Dong and R.W. Hardy (2001). Dietary microbial phytase supplementation and the utilization of phosphorus, trace minerals and protein by rainbow trout (Oncorhynchus mykiss Walbaum) fed soybean-meal based diets. Aquacult. Res. 32: 583-592.

Tudkaew, J., J. Gabaudan and W. Phromkunthong (2008). The supplementation of phytase RONOZYME® $P$ on the growth and the utilisation of phosphorus by sex reversed red tilapia (Oreochromis niloticus Linn.). Songklanakarin. J. Sci. Technol. 30: 17-24.

Verlhac-Trichet, V., J. Vielma, J. Dias, P. Rema, E. Santigosa, T. Wahli and K. Vogel (2014). The efficacy of a novel microbial 6-phytase expressed in aspergillus oryzae on the performance and phosphorus utilization of coldand warm-water fish: rainbow trout, Oncorhynchus mykiss, and Nile tilapia, Oreochromis niloticus. J. World Aquacult. Soc. 45: 367-379.

Vielma, J., K. Ruohonen and S.P. Lall 1999. Supplemental citric acid and particle size of fish bone-meal influence the availability of minerals in rainbow trout, Oncorhynchus mykiss (Walbaum). Aquacult. Nut. 5: 65-71.

Wood, R.J. and C. Serfaty-Lacrosniere (1992). Gastric acidity, atropic gastritis, and calcium absorption. Nutr. Rev. 50: 33-40.

Zhu Y., X. Qiu, Q. Ding, M. Duan and C. Wang (2014). Combined effects of dietary phytase and organic acid on growth and phosphorus utilization of juvenile yellow catfish Pelteobagrus fulvidraco. Aquaculture 439: 1-8. 